\title{
Prevalence of metabolic syndrome and of its specific components among adolescents from Niterói City, Rio de Janeiro State, Brazil
}

\author{
Prevalência de síndrome metabólica e de componentes específicos \\ da síndrome em adolescentes de Niterói, Rio de Janeiro, Brasil
}

Marlene M. Alvarez ${ }^{1,2}$, Ana Carolina R. e Vieira ${ }^{3}$, Rosely Sichieri ${ }^{3}$, Gloria V. da Veiga'

\author{
Department of Nutrition, \\ Universidade Federal do \\ Rio de Janeiro (UFRJ), Rio \\ de Janeiro, RJ, Brazil \\ ${ }^{2}$ Antônio Pedro Hospital, \\ Universidade Federal Fluminense \\ (UFF), Niterói, RJ, Brazil \\ ${ }^{3}$ Department of Social Medicine, \\ Universidade do Estado do \\ Rio de Janeiro (UERJ), Rio \\ de Janeiro, RJ, Brazil
}

\author{
Correspondence to: \\ Gloria V. da Veiga \\ Instituto de Nutrição Josué de \\ Castro, Universidade Federal do \\ Rio de Janeiro, Centro de Ciências \\ da Saúde, \\ Av. Brigadeiro Trompowisky, $\mathrm{s} / \mathrm{n}^{\circ}$, \\ bloco $\mathrm{J}, 2^{\circ}$ andar \\ 21941-590 - Rio de Janeiro, RJ, \\ Brazil \\ grveiga@globo.com
}

Received on Oct/5/2010 Accepted on Jan/31/2011

\begin{abstract}
Objective: To compare the prevalence of metabolic abnormalities (MA) and metabolic syndrome (MS) assessed by different criteria among Brazilian adolescents. Subjects and methods: Weighted prevalence of MA and MS were estimated using criteria adapted from the International Diabetes Federation (IDF), National Cholesterol Education Program, Adult Treatment Panel III (NCEP/ATP III), and the World Health Organization (WHO) in a probabilistic sample of 577 students aged 12-19. Results: The most prevalent MA was low concentration of HDL-C as per IDF (32.5\%) and NCEP/ATP III (41.6\%) criteria and hypertension as per the WHO's criterion (12.4\%). Prevalence of MS using the NCEP/ATP III criterion (6.04\%) was five times higher than the WHO's $(1.1 \%)$ and the IDF's $(1.6 \%)$ criteria. As expected, MS was significantly higher among overweight than among non-overweight adolescents. Conclusion: Low prevalence of MS but high prevalence of some MA were found. These findings suggest that the diagnosis of MA is more relevant in clinical practice especially in overweight adolescents. Arq Bras Endocrinol Metab. 2011;55(2):164-70
\end{abstract}

Keywords

Adolescent; overweight; metabolic syndrome; high density lipoprotein; hypertension

\section{RESUMO}

Objetivo: Comparar a prevalência de alterações metabólicas (AM) e de síndrome metabólica (SM) avaliadas por três diferentes critérios nos adolescentes brasileiros. Sujeitos e métodos: Foram estimadas prevalências expandidas de AM e SM pelos critérios adaptados do International Diabetes Federation (IDF), National Cholesterol Education Program, Adult Treatment Panel III (NCEP/ATP III) e o World Health Organization (WHO), em uma amostra probabilística de 577 estudantes de 12 a 19 anos. Resultados: Baixa concentração de HDL-C foi a AM mais prevalente segundo critérios do IDF (32,5\%) e do NCEP/ATP III (41,6\%), e hipertensão pelo critério do WHO $(12,4 \%)$. A prevalência de SM pelo critério NCEP/ATP III $(6,04 \%)$ foi cinco vezes mais alta do que pelos critérios WHO $(1,1 \%)$ e IDF $(1,6 \%)$ e, como era esperado, foi significantemente mais elevada entre adolescentes com sobrepeso. Conclusão: Foram encontradas menores prevalências de SM e maiores prevalências de algumas AM. Esses resultados sugerem que o diagnóstico das AM é mais relevante na prática clínica especialmente para adolescentes com excesso de peso. Arq Bras Endocrinol Metab. 2011;55(2):164-70

\section{Descritores}

Adolescente; excesso de peso; síndrome metabólica; lipoproteína de alta densidade; hipertensão arterial

\section{INTRODUCTION}

$\mathrm{M}$ etabolic syndrome (MS) defined as a cluster of risk factors for cardiovascular diseases such as hypertriglyceridemia, low blood concentrations of HDL-C (high density lipoprotein cholesterol), hypertension, hyperglycemia, and abdominal adiposity, has 
increased among adolescents in several countries and overweight and obese youth are the more vulnerable $(1,2)$. In Brazil, the prevalence of overweight in adolescents has increased by six times in boys and nearly three times in girls over the period of 1974 to 2009 (3), however, few studies have evaluated the presence of MS among overweight Brazilian adolescents. The first study in Brazil was conducted by the Authors in a sample population from public schools of Niterói, Rio de Janeiro. Prevalence of MS, based on the presence of at least three metabolic abnormalities was $21.4 \%$ among overweight 12 to 19 -year-old girls and $0.1 \%$ in those classified as normal weight (4). In another study conducted in the city of Maracai, São Paulo the prevalence of MS among 6 to 16-year-old schoolchildren as defined by the $\mathrm{Na}$ tional Cholesterol Education Program, increased from $0.3 \%$ in those with normal weight to $10.7 \%$ and $34.5 \%$ in overweight and obese subjects, respectively (5).

Several criteria have been described to define MS among adults and, in general, all of them define it as the concomitant presence of three or more metabolic abnormalities (6). The criteria used to define MS in adolescents are commonly an adaptation of the criteria used for adults $(7,8)$ differing in variables such as the cut off points defining the metabolic abnormality. A systematic review of literature brought evidence that the prevalence of MS among adolescents varied from 2.2\% to $52.1 \%$ depending on the criterion adopted and the studied population (9). Therefore, lack of standardization in diagnostic criteria impairs the comparison of prevalence found in different studies and identification of the true magnitude of MS. In order to attenuate this situation and standardize the diagnosis criterion, the International Diabetes Federation (IDF) proposed a specific definition for adolescents which considers the increase of abdominal adiposity measured by waist circumference (WC) as being the priority abnormality that should be added to two or more metabolic abnormalities (10).

WC is an easily obtained measurement which has been used to predict abdominal adiposity. In adolescents, as with adults, this measurement is associated with the metabolic abnormalities of MS and, therefore with the risk of cardiovascular disease (11). The low prevalence of MS among adolescents in Brazil may be due to the diagnostic criteria used, since the prevalence of the syndrome's components is increasing among adolescents (12) and weight gain has also been clearly documented in national surveys $(3,13)$. Therefore, we compared the prevalence of MS among students, applying three diagnostic criteria and compared the prevalence of each specific metabolic abnormality included in the definition of MS.

\section{SUBJECTS AND METHODS}

This study was carried out from June to December of 2003 in a probabilistic sample of 12 to 19 -year-old adolescents from public schools of the city of Niterói, Rio de Janeiro state, in Brazil. Niterói has approximately 479.000 inhabitants. Sample size calculation was based on the data for 2001, when 25,102 students between the ages of 12 and 19 were enrolled in the 33 public schools. The sample size of 600 students was originally calculated based on the prevalence of $25 \%$ of hypercholesterolemia, at a $95 \%$ confidence interval, with $5 \%$ of precision and random class selection cluster sampling (14). As a $30 \%$ non-response was anticipated according to a pilot study, the total sample should therefore comprise 780 adolescents ( 26 classes with 30 students each). The classes were randomly distributed in 13 of the 33 schools. The needed sample to estimate, with a $95 \%$ confidence interval $(95 \% \mathrm{CI})$ and an absolute precision of five percentage points, a prevalence of $5 \%$ of MS (5), expecting a non-response of $30 \%$, was of 100 students. Considering a $40 \%$ high prevalence of any metabolic abnormality the needed sample would need to be of 360 adolescents. Of the 757 students that met the eligibility criteria (absence of any physical handicap that could interfere with the anthropometric evaluation, not be pregnant or breastfeeding, and not be on any medication that might interfere with the results of the tests) anthropometric data was obtained from 610 adolescents only ( 43 did not present authorization from their parents, 85 refused to participate, and 19 were not present on the day of the evaluation). An additional 33 adolescents had no blood samples, resulting in a total of 577 adolescents in this study.

Weight (digital scales) and height (portable stadiometer) were measured by trained anthropometrists. WC was measured at the smallest circumference of the trunk. Blood pressure was measured twice with adolescents seated and using an automated blood pressure recorder (Pro Check) with a 2-minute interval between the two measures. If the variation between the two measurements exceeded $15 \mathrm{mmHg}$, an additional measure was obtained and the average calculated. Adolescents were previously advised not to engage in physical activity one hour before, not to drink caffeinated 
drinks, and not to smoke at least 30 minutes before blood pressure measurement (14).

Glucose, HDL-C, and triglycerides were assessed using the automatized enzymatic method Extress Plus with blood samples collected after a 12-hour fasting period. All anthropometric and biochemical data collection procedures are described in detail by Alvarez and cols. (4) and Vieira and cols. (12).

The three criteria used to determine the presence of MS among the adolescents are presented in table 1 and they were adapted for the purpose of this study. When applying the criterion proposed by Viner and cols. (8) the cut off points for BMI according to sex and age and recommended by the International Obesity Task Force (15) were used to classify overweight. Also, fasting glycemia was used instead of the oral glucose tolerance test due to its practical aspects and viability in epidemiological studies. For Ford and cols. (7) and Zimmet and cols. (10) criteria, WC values in the $90^{\text {th }}$ percentile for age and sex were obtained according to the investigated sample's distribution. The use of WC values from the American population as a reference, suggested by the IDF, would have further reduced the prevalence of MS since prevalence of obesity in young Brazilians is not as high as the observed in the United States. The criteria suggested by IDF for the diagnosis of MS among adolescents up to 16 years old were used for all adolescents in this study in order to allow comparisons with the other criteria used in this study $(7,8)$. Hypertension was defined by sex, age, and height/age percentile, according to the Brazilian Society of Cardiology (BSC) (16) when the Viner and cols. (8) and Ford and cols. (7) criteria were applied.

To estimate the prevalence of metabolic abnormalities cut off points suggested by the BSC (16) were also used for HDL-C $(\leq 45 \mathrm{mg} / \mathrm{dL})$, triglycerides $(\geq 100$ $\mathrm{mg} / \mathrm{dL})$, and hypertension $\left(\geq 95^{\text {th }}\right.$ percentile for age, sex, and height by age percentile).

Data analysis was performed using the Statistical Analysis System software, version 8.2 (SAS, Institute Inc, Cary, NC). Weighted prevalence of metabolic abnormalities and of MS with 95\% confidence intervals were estimated by sex and nutritional status (overweight and not overweight) and were compared based on the chi-square test using SAS Surveyreg with a p-value $<0.05$ for statistical significance.

This research was approved by the Ethics Committee in Research of the Clementino Fraga Filho University Hospital at the Federal University of Rio de Janeiro, in accordance with the Declaration of Helsinki.
Table 1. Criteria used in diagnosing metabolic syndrome among adolescents

\begin{tabular}{|c|c|c|c|}
\hline Criteria & $\begin{array}{l}\text { Viner and cols. } \\
\text { (WHO)* }\end{array}$ & $\begin{array}{l}\text { Ford and cols. } \\
\text { (NCEP/ATP III) }^{\dagger}\end{array}$ & $\begin{array}{l}\text { Zimmet and cols. } \\
\text { (IDF) }^{\ddagger}\end{array}$ \\
\hline $\begin{array}{l}\text { Overweight/ } \\
\text { obesity }\end{array}$ & "| BMI & $s W C \geq 90^{\text {th }}$ & $s W C \geq 90^{\text {th }}$ \\
\hline HDL-C & $<35 \mathrm{mg} / \mathrm{dL}$ & $\leq 40 \mathrm{mg} / \mathrm{dL}$ & $<40 \mathrm{mg} / \mathrm{dL}$ \\
\hline Glucose & $\geq 110 \mathrm{mg} / \mathrm{dL}$ & $\geq 100 \mathrm{mg} / \mathrm{dL}$ & $\geq 100 \mathrm{mg} / \mathrm{dL}$ \\
\hline Hypertension & $\geq 95^{\text {th } \#}$ & $\geq 90^{\text {th }}$ & $\begin{array}{c}\geq 130 \mathrm{mmHg} \text { or } \\
\quad \geq 85 \mathrm{mmHg}\end{array}$ \\
\hline Triglycerides & $\geq 150 \mathrm{mg} / \mathrm{dL}$ & $\geq 110 \mathrm{mg} / \mathrm{dL}$ & $\geq 150 \mathrm{mg} / \mathrm{dL}$ \\
\hline MS" & $\begin{array}{c}3 \text { or }+ \\
\text { abnormalities }\end{array}$ & $\begin{array}{c}3 \text { or }+ \\
\text { abnormalities }\end{array}$ & $\begin{array}{l}W C \geq 90^{\text {th }}+2 \text { or } \\
\text { more abnormalities }\end{array}$ \\
\hline
\end{tabular}

* World Health Organization; ${ }^{\dagger}$ National Cholesterol Education Program, Adult Treatment Panel III; * International Diabetes Federation; ${ }^{\S}$ waist circumference taking into account sample distribution values; " body mass index (IOTF criterion); " metabolic syndrome; " Taking into account sex, age and height/age.

\section{RESULTS}

Prevalence of MS among the adolescents ranged from $1.1 \%$ to $6.0 \%$ depending on the criterion that was applied (Table 2). Prevalence was approximately five times greater when the Ford and cols. (7) criterion was used in comparison to the other two. Based on this reference, MS was significantly higher among boys than girls ( $13.8 \%$ vs. $2.4 \%, \mathrm{p}<0.001$ ). As expected, prevalence of MS was higher in overweight adolescents regardless of the criteria applied. According to Viner and cols. (8) and the IDF criteria prevalence of MS was observed only among overweight adolescents $(6.6 \%$ and $9.6 \%$ respectively). Based on the Ford and cols. (7) criterion prevalence was $21.5 \%$ in overweight and only $3 \%$ in non overweight adolescents.

Table 3 shows the prevalence of each metabolic abnormality according to the criterion used. Low blood concentration of HDL-C was the most prevalent metabolic alteration among all adolescents according to Ford and cols. (7) (41.6\%), IDF (10) (32.5\%) and BSC (16) $(56.3 \%)$ criteria. Among the boys, hypertension was the second most prevalent abnormality, and the first according to Viner and cols. (8), varying from $27 \%$ to $30 \%$. Hypertension was significantly higher among boys than girls. The prevalence of hyperglycemia was $22.5 \%$ according to the criteria that used the cut off point $\geq 100$ $\mathrm{mg} / \mathrm{dL}$; however, prevalence decreased significantly to $5 \%$ when the cut off point $\geq 110 \mathrm{mg} / \mathrm{dL}$ was utilized in conformity with the Viner and cols. (8) criterion. Hypertriglyceridemia was the least prevalent abnormality $(\sim 3 \%)$ when Viner and cols. (8) and IDF (10) criteria were applied. However, when the cut off point proposed by BSC was used prevalence reached $20 \%$. 
Table 2. Metabolic syndrome weighted prevalence in diagnosed adolescent students from public schools in Niterói, RJ, Brazil

\begin{tabular}{|c|c|c|c|c|}
\hline $\begin{array}{l}\text { Metabolic syndrome } \\
\text { criterion }\end{array}$ & $\begin{array}{c}\text { Total }(\mathrm{N}=577) \\
\%(95 \% \mathrm{Cl})^{\dagger}\end{array}$ & $\begin{array}{c}\text { Boys }(\mathrm{N}=210) \\
\%(95 \% \mathrm{Cl})^{\dagger}\end{array}$ & $\begin{array}{c}\text { Girls }(\mathrm{N}=367) \\
\%(95 \% \mathrm{Cl})^{\dagger}\end{array}$ & p-value \\
\hline Viner and cols. (WHO) & $1.1(0.4-2.8)$ & $1.0(0.2-5.3)$ & $1.1(0.3-3.8)$ & 0.94 \\
\hline Ford and cols. (NCEP/ATP III) & $6.0(3.0-7.8)$ & $13.8(8.5-21.7)$ & $2.4(1.0-5.7)$ & $<0.001$ \\
\hline \multirow[t]{2}{*}{ Zimmet and cols. (IDF) } & $1.6(0.6-3.9)$ & $3.1(0.9-9.8)$ & $0.9(02-3.9)$ & 0.17 \\
\hline & & $\begin{array}{c}\text { Overweight }^{\ddagger} \\
\mathrm{N}=97\end{array}$ & $\begin{array}{c}\text { Non-overweight } \\
\mathrm{N}=\mathbf{5 1 3}\end{array}$ & p-value \\
\hline Viner and cols. (WHO) & & $6.6(2.5-16.3)$ & 0 & - \\
\hline Ford and cols. (NCEP/ATP III) & & $21.5(12.6-34.2)$ & $3.0(1.7-5.3)$ & $<0.001$ \\
\hline Zimmet and cols. (IDF) & & $9.6(3.8-22.4)$ & 0 & - \\
\hline
\end{tabular}

† 95\% Confidence Interval; ₹According to IOTF criterion [15] grouping all participants falling above the overweight cut off (both overweight and obese).

Table 3. Weighted prevalence of metabolic abnormalities according to different criteria for diagnosing metabolic syndrome and based on cut off points proposed by the Brazilian Society of Cardiology in adolescent students from public schools in Niterói, RJ, Brazil

\begin{tabular}{|c|c|c|c|c|}
\hline Criteria & $\begin{array}{l}\text { Total }(\mathrm{N}=577) \\
\%(95 \% \mathrm{Cl})\end{array}$ & $\begin{array}{c}\text { Boys }(\mathrm{N}=210) \\
\%(95 \% \mathrm{Cl})\end{array}$ & $\begin{array}{c}\text { Girls (N = 367) } \\
\%(95 \% \mathrm{Cl})\end{array}$ & p-value \\
\hline \multicolumn{5}{|l|}{ Viner and cols. (WHO) } \\
\hline Overweight/obesity (BMI) & $15.8(12.4-19.9)$ & $17.6(13.0-23.5)$ & $15.0(10.5-20.8)$ & 0.48 \\
\hline $\mathrm{HDL}-\mathrm{C} \leq 35 \mathrm{mg} / \mathrm{dL}$ & $6.1(3.1-9.1)$ & $6.8(1.4-12.8)$ & $5.8(2.2-9.4)$ & 0.75 \\
\hline Triglycerides $\geq 150 \mathrm{mg} / \mathrm{dL}$ & $3.7(1.9-5.4)$ & $3.6(1.1-6.1)$ & $3.7(1.4-5.9)$ & 0.98 \\
\hline Glucose $\geq 110 \mathrm{mg} / \mathrm{dL}$ & $5.0(1.3-8.7)$ & $5.1(2.2-7.9)$ & $5.0(0.1-9.8)$ & 0.96 \\
\hline $\begin{array}{l}\text { Hypertension } \geq 95 \text { percentile (SBP and/ } \\
\text { or DBP) }\end{array}$ & $12.4(8.1-16.6)$ & $27.0(19.0-34.9)$ & $5.7(2.6-8.9)$ & $<0.001$ \\
\hline \multicolumn{5}{|l|}{ Ford and cols. (NCEP/ATP III) } \\
\hline Overweight/obesity (WC > P90) & $9.0(6.3-12.9)$ & $9.7(5.9-15.7)$ & $8.7(5.5-13.6)$ & 0.73 \\
\hline $\mathrm{HDL}-\mathrm{C} \leq 40 \mathrm{mg} / \mathrm{dL}$ & $41.6(30.6-52.6)$ & $38.8(28.2-49.3)$ & $42.9(30.4-55.4)$ & 0.37 \\
\hline Triglycerides $\geq 110 \mathrm{mg} / \mathrm{dL}$ & $14.5(11.2-17.9)$ & $19.0(12.7-25.2)$ & $12.5(7.9-17.0)$ & 0.11 \\
\hline Glucose $\geq 100 \mathrm{mg} / \mathrm{dL}$ & $22.5(13.3-31.7)$ & $29.2(16.8-41.5)$ & $19.4(8.8-29.9)$ & 0.14 \\
\hline $\begin{array}{l}\text { Hypertension } \geq 90^{\text {th }} \text { percentile } \\
\left(\mathrm{SBP}^{\star} \text { and/or } \mathrm{DBP}^{+}\right)\end{array}$ & $16.6(11.7-21.4)$ & $32.9(24.6-41.2)$ & $9.1(4.9-13.4)$ & $<0.001$ \\
\hline \multicolumn{5}{|l|}{ Zimmet and cols. (IDF) } \\
\hline Overweight/obesity (WC > P90) & $9.0(6.3-12.9)$ & $9.7(5.9-15.7)$ & $8.7(5.5-13.6)$ & 0.48 \\
\hline $\mathrm{HDL}-\mathrm{C}<40 \mathrm{mg} / \mathrm{dL}$ & $32.5(23.6-41.4)$ & $28.7(19.0-38.5)$ & $34.3(23.6-44.9)$ & 0.31 \\
\hline Triglycerides $\geq 150 \mathrm{mg} / \mathrm{dL}$ & $3.7(1.9-5.4)$ & $3.6(1.1-6.1)$ & $3.7(1.4-5.9)$ & 0.98 \\
\hline Glucose $\geq 100 \mathrm{mg} / \mathrm{dL}$ & $22.3(13.3-31.7)$ & $29.2(16.8-41.5)$ & $19.4(8.9-29.9)$ & 0.14 \\
\hline Hypertension 130/85 mmHg & $12.5(7.9-17.05)$ & $30.3(21.1-39.5)$ & $4.4(1.6-7.2)$ & $<0.001$ \\
\hline \multicolumn{5}{|l|}{$\mathrm{BSC}^{\ddagger}$} \\
\hline $\mathrm{HDL}-\mathrm{C} \leq 45 \mathrm{mg} / \mathrm{dL}$ & $56.3(42.9-69.8)$ & $55.9(42.1-69.8)$ & $56.5(41.7-71.4)$ & 0.92 \\
\hline Triglycerides $\geq 100 \mathrm{mg} / \mathrm{dL}$ & $20.4(16.0-24.9)$ & $24.8(18.1-31.5)$ & $18.4(12.5-24.3)$ & 0.16 \\
\hline Glucose $\geq 100 \mathrm{mg} / \mathrm{dL}$ & $22.5(13.3-31.7)$ & $29.2(16.8-41.5)$ & $19.4(8.8-29.9)$ & 0.14 \\
\hline $\begin{array}{l}\text { Hypertension } \geq 95 \text { percentile } \\
\text { (SBP and/or DBP) }\end{array}$ & $12.4(8.1-16.6)$ & $27.0(19.0-34.9)$ & $5.7(2.6-8.9)$ & $<0.0001$ \\
\hline
\end{tabular}

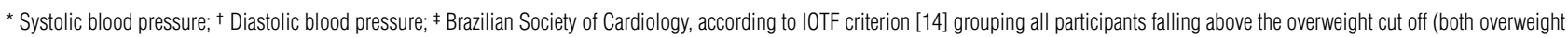
and obese).

\section{DISCUSSION}

Presence of MS in young people has recently been associated to the premature presence of chronic diseases in adulthood (2), which highlights the importance of investigating the problem among this age group. Since the last decade MS has been investigated among youth, especially in developed countries $(17,1)$, although few studies were conducted in developing countries including Brazil $(4,5)$. In general, boys are at a higher risk than girls $(17,18)$, as are the Americans with Hispanic origin, and black people are more than white $(19,20)$. Considerably higher prevalence is observed among overweight and obese adolescents when compared to normal weight adolescents $(1,4,5)$. 
However, a diagnosis criterion that is accepted worldwide has not yet been established, specifically for adolescents; and the present study shows that the application of different criteria can result in great differences in the estimated prevalence. When using the criterion adapted for adolescents by Ford and cols. (7) based on the NCEP/ATP III (21) for adults, MS was almost five times more prevalent than when evaluated by the other two criteria. Other studies $(17,1)$ also highlight the great variability of MS prevalence in the same sample using several definitions. The lower cut off for classification of hypertension and hypertriglyceridemia, are probably the main contributors to the higher prevalence of MS obtained by applying the NCEP/ATP III criterion adapted for adolescents.

Higher MS prevalence among boys compared to girls is in accordance others studies $(17,1)$. This difference was probably due to higher prevalence (although not significant) of hypertriglyceridemia among boys, mainly when the NCEP/ATP III criterion was used. Triglyceride metabolism can be affected by the consumption of alcohol (22) and studies with Brazilian adolescents show that the intake of alcohol is more prevalent in boys than in girls $(23,24)$. Moreover in the last 30 years the increasing prevalence of overweight in Brazil was higher in boys than in girls $(3,13)$. Prevalence of hypertension was also higher in boys than in girls.

The association between overweight and the presence of MS was observed in this study, regardless of the criterion used, as was verified in several other studies $(9,5,17,1)$. This association shows the importance of measures for preventing and controlling obesity starting at childhood and emphasizes the need to diagnose overweight children as a priority in clinical practice.

In an attempt to unify the definitions of MS for universal use among adolescents, the IDF (10) considered abnormalities commonly associated with cardiovascular risk as being components of the syndrome, using cut off points that were specific for adolescents up to the age of 16 and establishing as a main criterion the presence of high WC values, linked to two other abnormalities among the components of the syndrome. The use of the IDF criterion adapted for adolescents up to the age of 19 in our study may have avoided the underestimation of the prevalence, since the use of the adult criterion for adolescents decreased the sensitivity of the IDF criterion in the diagnosis of MS as verified by other authors $(25,26)$.

Cook and cols. (17) stated that the choice of specific cut off points for an age group is still premature and does not bestow greater reliability to the IDF criterion, highlighting the need for more longitudinal studies to identify cardiovascular risk factors, especially among overweight youth and in order to understand the development of MS. Our data indicating that most of MS prevalence is due to excess in adiposity as supported by Reaven's (6) proposal of better understanding the physiopathological meaning of MS and its clinical significance. Particularly in adolescence, it is important to identify the prevalence of metabolic abnormalities, mainly of those related to environmental factors that may be prevented regardless of the cluster of risk factors. In the present study the most prevalent metabolic abnormality was low concentration of HDL-C, which is considered an antiatherogenic lipoprotein (27) that in low concentrations can be an isolated risk factor for cardiovascular diseases. Other studies $(18,2)$ have also identified this component as one of the main alterations found among young people with MS.

The reduction of blood HDL-C values can be associated with the lack of regular physical activity. In Brazil, physical activity among youth is not common and levels of inactivity are high (28).

Another important abnormality verified in this study was hypertension, mainly among boys, similar to what has been observed in other studies $(17,5)$. The prevalence of this component of MS among all adolescents was around $12 \%$ when evaluated by the criterion adapted from the WHO (8). When compared to other studies carried out in Brazil that used the same criterion to classify hypertension this value was similar to that found by Moura and cols. (29) in children and adolescents from private and public schools from a city in Northeastern Brazil (9.4\%), and by Silva and cols. (30) in adolescents seen at a clinic (13\%) in the city of São Paulo. When the cut off point adapted by Ford and cols. (7) based on the NCEP/ATP III criterion (21) and which defines a lower value of diastolic and systolic pressure to classify normal blood pressure was applied, prevalence increased to $16 \%$. In other studies with adolescents $(9,17)$ great variation in the prevalence of hypertension was also observed as a consequence of different cut off points used in the diagnosis criterion. High prevalence of hypertension could be due to increased random error in the measurements since a digital manometer has limitations, specially in measuring diastolic pressure, therefore there was the need to calibrate it more frequently, which was done during the study. On the other hand, this equipment is easy to use 
and a similar model was used to evaluate hypertension in Japanese children and adolescents (31).

The difficulty in comparing MS prevalence in adolescents obtained in different studies is due to changes in diagnostic criteria and also changes in the cut offs used to detect the presence of metabolic abnormalities. Ferranti and cols. (20) clearly showed that small changes in the cut off points defining lipemic profile and alterations in WC measurements were sufficient to double the prevalence of MS from $4.2 \%$ to $9.2 \%$ among American adolescents. In the present study the prevalence of hyperglycemia is up to 4 times greater when the cut off point $\geq 100 \mathrm{mg} / \mathrm{dL}$ is used instead of $\geq 110 \mathrm{mg} / \mathrm{dL}$. Also in relation to HDL-C, a simple change in the symbol $(<$ or $\leq 40 \mathrm{mg} / \mathrm{dL})$ verified between the IDF (11) and Ford and cols. (7) criteria, resulted in differences of approximately $10 \%$ in the prevalence of this alteration, which will certainly produce great impact upon the prevalence of MS.

In 2005 in Brazil the BSC (16) changed the reference values to classify lipemic disorders in the 2 to 19-year-old age group. The cut off points for triglycerides, total cholesterol, and LDL-C were reduced; and for HDL-C was increased when compared with the previous recommendation that was based on the NCEP/ ATP III (21). These changes explain the greater prevalence of metabolic abnormalities that was found when this criterion was used.

One possible limitation in our study that could have underestimated the prevalence of MS was the use of fasting glycemia instead of the oral glucose tolerance test (OGTT), in conformity to the criterion proposed by Viner and cols. (8). However, this underestimation would be more likely among obese adolescents and the prevalence of obesity (BMI values greater than the corresponding cut off point according to age and sex) was only $2 \%$.

In conclusion, the use of different diagnostic criteria leads to huge differences in the prevalence of MS, although prevalence of MS for most classifications was low and more noticeable among overweight adolescents. Thus, MS in adolescence presents a complex, yet controversial issue and only longitudinal studies would prove the noxious effects of metabolic abnormalities in adolescence which, clustered or not, could produce the risk of diseases in adulthood.

Acknowledgements: Grant support: we thank the National Council for Scientific and Technological Development (CNPq) for financially supporting this research.
Disclosure: no potential conflict of interest relevant to this article was reported.

\section{REFERENCES}

1. Lee S, Bacha F, Gungor N, Arsalanian AS. Comparinson of different definitions of metabolic syndrome: relation to abdominal adiposity, insulin resistance, adiponectin, and inflammatory biomarkers. J Pediatr. 2008;152(2):177-84.

2. Morrinson JA, Friedman LA, Wang P, Glueck CJ. Metabolic syndrome in childhood predicts adult metabolic syndrome and type 2 diabetes mellitus 25 to 30 years later. J Pediatr. 2008;152(2):201-6.

3. Instituto Brasileiro de Geografia e Estatística. Pesquisa de Orçamentos Familiares - POF 2008-2009. Antropometria e Estado Nutricional de Crianças, Adolescentes e Adultos no Brasil [article online], 2010. Available from: http://www.ibge.gov.br. Access on: Dec 3, 2010.

4. Alvarez MA, Vieira ACR, Moura AS, Veiga GV. Insulin resistance in Brazilian adolescent girls: association with overweight and metabolic disorders. Diabetes Res Clin Pract. 2006;74(2):183-8.

5. Seki M, MatsuoT, Carrilo AJF. Prevalence of metabolic syndrome and associated risk factors in Brazilian schoolchildren. Public Health Nutr. 2008;12(7):947-52.

6. Reaven GM. The metabolic syndrome: requiescat in peace. Clin Chem. 2005;51(6):931-8.

7. Ford ES, Ajani UA, Mokdad AH. The metabolic syndrome and concentrations of C-reactive protein among U.S. Youth. Diabetes Care. 2005;28(4):878-81.

8. Viner RM, SegalTY, Lichtarowicz-krynska E, Hindmarsh. Prevalence of the insulin resistance syndrome in obesity. Arch Dis Child. 2005;90(1):10-4.

9. Moraes ACF, Fulaz CS, Netto-Oliveira ER, Reichert FF. Prevalência da síndrome metabólica em adolescentes: uma revisão sistemática. Cad Saude Publica. 2009;25(6):1195-202.

10. Zimmet P, Alberti KGMM, Kaufman F, Tajima N, Silink M, Arsalanian $S$, et al. IDF Consensus Group: the metabolic syndrome in children and adolescents - an IDF consensus report. Pediatr Diabetes. 2007;8(5):299-306.

11. Lee $S$, Bacha F, Gungor N, Arsalanian AS. Waist circunference is an independent predictor of insulin resistance in black and white youths. J Pediatr. 2006;148(2):188-94.

12. Vieira ACR, Alvarez MM, Kanaan S, Sichieri R, Veiga GV. Body mass index preticting hiperglycemia and serum lipid changes in Brazilian adolescents. Rev Saude Publica. 2009;43(1):44-52.

13. Veiga GV, Cunha AS, Sichieri R. Trends in overweigh among adolescents living in the poorest and richest regions of Brazil. Am J Public Health. 2004;94(9):1544-8.

14. Alvarez MM, Vieira ACR, Sichieri R, Veiga GV. Associação das medidas antropométricas de localização de gordura central com os componentes da síndrome metabólica em uma amostra probabilística de adolescentes de escolas públicas. Arq Bras Endocrinol Metab. 2008;52(4):649-57.

15. Cole JT, Bellizi CM, Flegal MK, Dietzs HW. Establishing a standard definition for child overweight and obesity worldwide: international survey. BMJ. 2000;320(7244):1240-3.

16. Sociedade Brasileira de Cardiologia. I Diretriz de Prevenção da Aterosclerose na Infância e na Adolescência. Arq Bras Cardiol. [article online]. 2005;85(suppl.6):3-36. Available from: http://www. scielobr/pdf/abc/v85s6. Access on: Apr 14, 2009.

17. Cook $S$, Auinger $P$, Chaoyang L, Ford ES. Metabolic syndrome rates in United States Adolescents, from the National Health and Nutrition Examination Survey, 1999-2002. J Pediatr. 2008;152(2):165-70. 
18. Ford ES, Li C, Zhao G, Pearson WS, Mokdad AH. Prevalence of the metabolic syndrome among U.S. adolescents using the definition from the International Diabetes Federation. Diabetes Care. 2008;31(3):587-9.

19. Weiss R, Dziura J, Burgert TS, Tamborlane WV, Taksali SE, Yeckel $\mathrm{CW}$, et al. Obesity and the metabolic syndrome in children and adolescents. N Engl J Med. 2004;350(23):2362-74.

20. Ferranti SD, Gauvreau K, Ludwig DS, Neufeld EJ, Newburger JW, Rifai N. Prevalence of the metabolic syndrome in Americans adolescents, findings from the Third National Health and Nutrition Examination Survey. Circulation. 2004;110(16):2494-7.

21. NCEP-Executive Summary of the Third Report of the National Cholesterol Education Program Expert Panel on Detection, Evaluation, and Treatment of High Blood Cholesterol in Adults (Adult Treatment Panel III). JAMA. 2001;285(19):2486-97.

22. Taskinen MR, Välimäki M, Nikillä EA, Kriusi T, Ylikahri R. Sequence of alcohol-induced initial changes in plasma lipoproteins (VLDL and HDL) and lipolytic enzymes in humans. Metabolism. 1985;34(2):112-9.

23. Vieira DL, Ribeiro M, Romano M, Laranjeira RR. Álcool e adolescentes: estudo para implementar políticas municipais. Rev Saúde Pública. 2007;41(3):396-403.

24. Souza DPO, Areco KN, Silveira Filho DX. Alcohol and alcoholism among Brazilian adolescent public-school students Rev Saúde Pública. 2005;39(4):585-92.

25. Druet $\mathrm{C}$, Ong $\mathrm{K}$, Marchal CL. Metabolic syndrome in children: comparinson of the International Diabetes Federation 2007 con- sensus with an adaptated Nathional Cholesterol Education Program definition in 300 overweight and obese French children. Horm Res Paediatr. 2010;73(3):181-6.

26. Lee K. Waist circumference percentile criteria for the pediatric metabolic syndrome in Korean adolescents. Asia Pac J Clin Nutr. $2008 ; 17(3): 422-8$.

27. Srinivasan SR, Myers L, Berenson GS. Distribuition and correlates of non-high-density lipoprotein cholesterol in children: the Bogalusa Heart Study. Pediatrics [serial on the Internet], 2002;110;e29 DOI: 10.1542/peds.110.3.e29. Available from: http:// www.pediatrics.org/cgi/content/full/110/3/e29. Acessed 10 august 2009. Access on: Apr 14, 2009.

28. Hallal PC, Dumith SC, Bastos JP, Reichert FF, Siqueira FV, Azevedo MR. Evolução da pesquisa epidemiológica em atividade física no Brasil: revisão sistemática. Rev Saude Publica. 2007;41(3):453-60.

29. Moura AA, Silva MAM, Ferraz MRMT, Rivera IR. Prevalência de pressão arterial elevada em escolares e adolescentes de Maceió. J Pediatr (Rio J). 2004;80(1):35-40.

30. Silva RCQ, Miranda WL, Chacra A, Dib AS. Metabolic syndrome and insulin resistance in normal glucose tolerant Brazilian adolescents with family history of type diabetes. Diabetes Care. 2005;28(3):716-8.

31. Nishina M, Kikuchi T, Yamazaki H, Kameda K, Hiura M, Uchiyama M. Relationship among systole blood pressure, serum insulin and leptin, and visceral fat accumulation in obese children. Hypertens Res. 2003;26(4):281-8. 